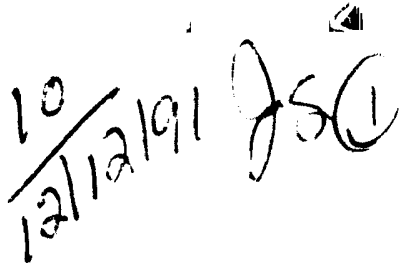

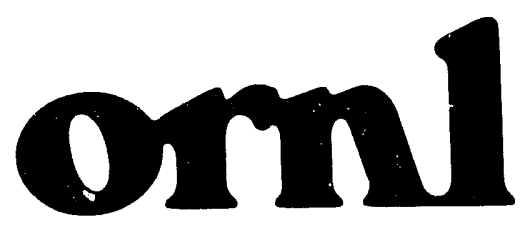

OAK RIDGE NATIONAL LABORATORY

MARTIN MARIETRA

\section{Marketable Permits for Controlling Sulphur Dioxide Emissions}

Douglas R. Hale

David J. Bjornstad 
This report has ren reproduced directly trom the avestable copy

Available to DOE and DOE contractors trom the Office of Scientific and Technical Intormation, P O Box 62. Oak Ridge. TN 37831; prices available from (615) 576-8401, FTS 626-840

Available to the public from the Netional Technical Information Service, U.S. Department of Commerce, 5285 Port Royal Rd., Springtield, VA 22161.

This report was prepared as an account of work sponsored by an agency of the United States Government. Nelther the United States Government nor any agency therent. nor any of their employees. makes any warranty, express or implied, or assumes any legal liability or responsibility for the accuracy, completeness, or usetulness of any information, apparatus, product, or process disclosed. or represents that its use would not intringe privately owned rights. Reterence herein to any spocific commercia! product. process, or service by trade name. trademark, manutacturer, or othurwise, does not necessarily constitute or imply its endorsement recommendation, or favoring by the United States Government or any agency inereot. The views and opinions of authors expressed herein do not necessarily $s$ ate of reflect those of the United States Government or any agency thereot 


\author{
Douglas R. Hale \\ Energy Information Administration \\ U.S. Department of Energy \\ and
}

David J. Bjornstad

Energy Division

Oak Ridge National Laboratory

DATE PUBLISHED - DECEMBER 1991

Prepared by the

Energy Division

OAK RIDGE NATIONAL LABORATORY

Oak Ridge, Tennessee 37831-6205

managed by

MARTIN MARIETTA ENERGY SYSTEMS, INC.

for the

U.S. DEPARTMENT OF ENERGY

under Contract No. DE-AC05-84OR21400 


\section{TABLE OF CONTENTS}

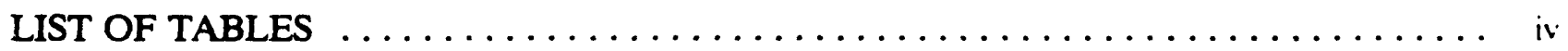

LIST OF FIGURES $\ldots \ldots \ldots \ldots \ldots \ldots \ldots \ldots \ldots \ldots \ldots \ldots \ldots \ldots \ldots \ldots \ldots \ldots \ldots \ldots$

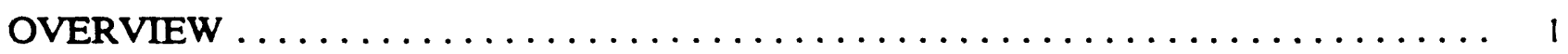

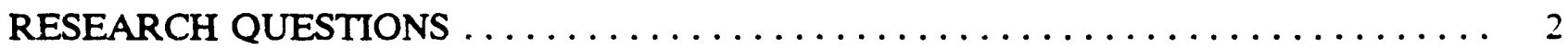

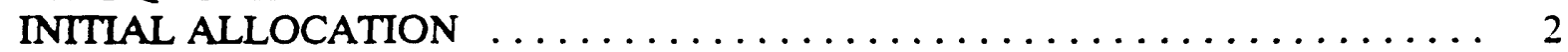

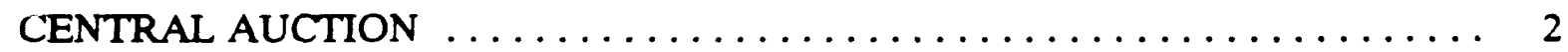

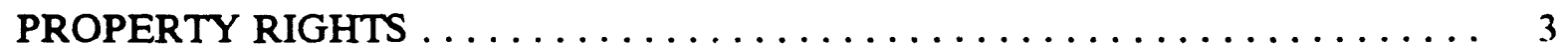

SUMMARY OF EXPERIMENTAL RESULTS $\ldots \ldots \ldots \ldots \ldots \ldots \ldots \ldots \ldots \ldots \ldots$

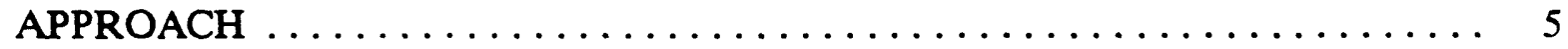

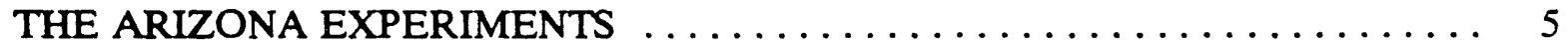

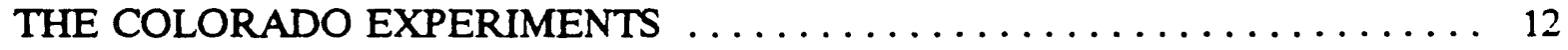

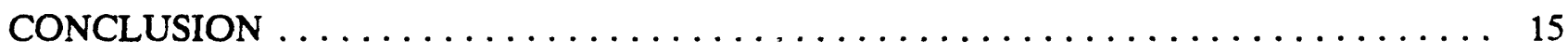

POSTSCRIPT $\ldots \ldots \ldots \ldots \ldots \ldots \ldots \ldots \ldots \ldots \ldots \ldots \ldots \ldots \ldots \ldots \ldots \ldots \ldots$ 


\section{LIST OF TABLES}

Table 1. Common conditions of initial allocation experiments (Arizona) $\ldots \ldots \ldots \ldots$

Table 2. First period efficient holdings and initial endowments of subjects . . . . . . . 6

Table 3. Conditions of permit type experiments (Colorado) $\ldots \ldots \ldots \ldots \ldots \ldots \ldots \ldots \ldots \ldots$

Table 4. Average ratio of realized cost to minimum cost $\ldots \ldots \ldots \ldots \ldots \ldots \ldots \ldots \ldots 14$

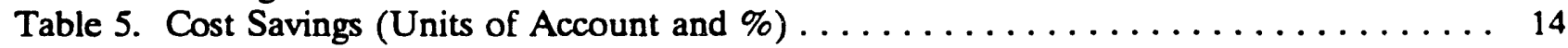

\section{LIST OF FIGURES}

Fig. 1 Market Prices: Baseline Experiments $\ldots \ldots \ldots \ldots \ldots \ldots \ldots \ldots \ldots \ldots \ldots$

Fig. 2 Average Market Efficiencies: Baseline Experiments $\ldots \ldots \ldots \ldots \ldots \ldots \ldots \ldots \ldots \ldots \ldots$

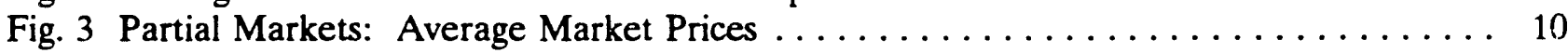

Fig. 4 Partial Markets: Efficiency Gains $\ldots \ldots \ldots \ldots \ldots \ldots \ldots \ldots \ldots \ldots \ldots \ldots \ldots \ldots 11$ 


\title{
MARKETABLE PERMITS FOR CONTROLLING SULPHUR DIOXIDE EMISSIONS
}

\author{
Douglas R. Hale \\ and \\ David J. Bjornstad
}

\section{OVERVIEW}

During the summer and fall of 1990 , the Congress met in conference committee to reconcile differences in proposed amendments to the Clean Air Act. One issue was the definition of a marketable permit scheme to reduce sulphur dioxide emissions from about 16 million tons per year in 1987 to no more than 8.9 million tons per year in 2001. Under the proposed legislation, the Federal Government would distribute permits to large sellers of electricity, mainly utilities, who would either "spend" the permits as they emitted sulphur dioxide or trade the permits if their emissions fell below their permit allotments. The proposed distribution of permits would be sufficient to cover a portion of historical emissions of existing power plants, but other large sellers of electricity, including independent power producers, would be required to obtain permits either through direct purchases or through a federally sponsored auction. Because a facility could emit sulphur dioxide only if its holdings of permits were sufficient to cover its emissions, the permits would become an economic resource much like capital, labor, and fuel. Emitters would trade off the costs of more expensive fuel containing less sulphur or more expensive pollution control equipment against the cost of purchasing permits. In this way, the bills' sponsors hoped to achieve efficiencies in pollution control that are similar to those commonly found in markets for private goods.

The purpose of this paper is to describe research sponsored by the Energy Information Administration (EIA) at the Oak Ridge National Laboratory (ORNL) into the nature of the auctions described in the bills. The research was undertaken at the request of the House Committee on Energy and Commerce to assess how various provisions in the bills might affect the workings of the market. Because the project called for the analysis of market mechanisms that do not now exist, a "laboratory" approach was applied in which artificial markets are created using computerized trading, volunteer subjects, and cash incentives to mimic the markets being studied. Dr. Mark Isaac, at the University of Arizona, and Dr. Jamie Kruse, at the University of Colorado, led teams that designed and conducted the laboratory experiments.

${ }^{1}$ The authors are Director of the Division of Quality Assurance, Office of Statistical Standards, Energy Information Administration, U.S. Department of Energy, and Leader of the Energy and Environmental Economics Group, Energy Division, Oak Ridge National Laboratory, respectively. 


\section{RESEARCH QUESTIONS}

The House and Senate bills explicitly introduced provisions to protect current emitters, to promote beneficial permit trades and to limit uncertainty about permit availability in the future. The research focused upon the efficiency implications of these provisions.

Does granting the initial allocation of permits rather than selling them affect efficiency?

Would a mandatory central auction for some portion of the overall permit allotment promote beneficial exchanges that might not otherwise occur?

How does the nature of the permit -- its life, whether it can be banked for future use, and the availability of sequences of permits (e.g., a five-year permit) -- affect efficiency?

\section{INITIAL ALLOCATION}

The bills described a "revenue neutral" auction where existing utilities would receive the bulk of the available permits from the government for free. Except for various accounts set aside for special cases and a forced central market described below, each utility's share of the allocation would equal its average 1985-1987 fossil fuel use relative to average fossil fuel use for all electricity generation. Each utility's annual allocation for 1996-2000 was calculated in the House bill, for example, as 2.5 pounds of sulfur dioxide per million Btus of fuel used in the base period. After the year 2000 , the annual allocation would drop to 1.8 pounds of sulfur dioxide per million Btus normalized to make industry emissions total 8.9 million tons. The Senate bill had other formulas for establishing emissions limits.

Under all formulas, utilities that emit less than the thresholds would have surplus permits. Those that emit more would require additional permits to maintain operations. Since the total supply would be less than anticipated requirements, low emissions rate utilities would have a potentially valuable right that they could sell.

Granting permits to utilities gives them a guaranteed minimum emissions potential and also increases their wealth by the value of the permits. Since the utilities would pay nothing, it is possible that they would not efficiently use their endowments. They may, for examples, either treat their permits as free inputs or hoard them for speculation. The research question was whether granting permits rather than selling them affects efficiency.

\section{CENTRAL AUCTION}

Members of Congress have been concerned that an active market for the sale and purchase of permits would not spontaneously develop. This could handicap producers without initial allotments and could inhibit development of new generating capacity. To encourage trade, the bills established a central market in which a small proportion $(2.5 \%-10 \%)$ of the permits distributed to utilities would be offered for sale. The Federal Government would sell these permits at auction and would rebate the proceeds to the utilities who originally held the claim to them. 
The central market would be the one place where independent power producers, new generators, and other large sulphur dioxide sources could obtain permits if utilities would not se!l them voluntarily. The central ("mandatory") market would also give a price signal to the utilities and their public utility commissions about the value of the permits and the revenues forgone by "hoarding" permits.

How to sell permits in an auction is a surprisingly difficult question. Economists typically argue for a sealed bid, second price auction. In this system, bidders submit a schedule of bid prices and guarantees (e.g., 10 units at \$4, 15 units at \$3-3.99, 20 units at all prices less than \$3.00) at which they will buy and/or sell. The auctioneer then awards the available supply to the highest bidder or bidders, but only charges the price offered by the highest rejected bid. If, for example, a $\$ 3.00$ bid just exhausted available supplies, and the next highest, but rejected, bid were $\$ 2.75$, all successful bidders would be paid a uniform price of \$2.75. By contrast to the second price auction, the U.S. Treasury uses a discriminatory auction where successful bidders pay whatever price they bid, and only the lowest accepted bid is announced.

Intuitively, the second price auction has merit because bidders can reveal it a value of a permit to them without having that information used against them. As a result, the ust of strategy is reduced and the uniform price is generally an accurate indicator of the private value of the good. The discriminatory price auction would raise more revenue (and thus provide a stronger incentive for sellers to offer permits) if buyers were to persist in revealing their truc underlying valuations. But, buyers would have an incentive to engage in strategic bidding (e.g., guessing at the level of the lowest winning bid). The bills seemed to describe aspects of both pricing rules.

The research question was whether a small mandated market would actually promote efficient, cost saving trades.

\section{PROPERTY RIGHTS}

Permits confer a property right, the value of which depends upon the precise nature of the permit. Under both bills permits would only authorize otherwise legal emissions; they would not be a license to ignore state implementation plans or emission reduction orders by local air pollution control boards. A single year permit would expire, whether or not used, in its denomination year. This would encourage the trading of unused permits, but would complicate multi-year planning. A perpetuity would either last until used or would confer the right to emit specified quantities of sulphur dioxide in every year, forever. An indefinite life reduces uncertainty and simplifies long-term planning, but accommodates hoarding because the permit does not depreciate. Bundles of single year permits could be created (i.e., a five-year permit) to ensure a stream of pollution rights over time. Such assurances might be required by investors in new facilities or facilities without permit endowments. However, the sale of bundles today effectively removes permits from markets and could cause the time distribution of emissions to vary. Banking of one year permits, if allowed, can take on the features of perpetuities and bundles, but reduces the effectiveness of an annual emission ceiling. The research question was what kind of permit best promotes efficiency. 


\section{SUMMARY OF EXPERIMENTAL RESULTS}

To answer these questions Drs. Isaac and Kruse ran a series of 27 experiments. One feature of the experimental method is that the theoretically lowest cost method of reducing sulphur dioxide emissions and the associated competitive price of the permits can be calculated in advance for each variation and compared to the performance of the computerized markets using volunteer subjects. Cost savings relative to the least cost solution is reported as one indicator of efficiency in the experiments. Differences in emissions profiles are not considered in the efficiency measure.

All of the experiments used a second price auction to price permits. Price discrimination experiments could not be conducted in the time available for the study. Unless otherwise noted, the results are for single period permits that must be used within their denomination period ("year").

\section{The experiments found}

- The granting of permits to subjects followed by a mandatory second price auction led to highly efficient results compared both to the government selling them and to the competitive ideal.

A revenue neutral auction allowed emitters who initially held permits to bid higher than efficient prices in order to "hoard" permits, because they would get a revenue rebate to cover their expenditures.

- Mandatory auctions improved efficiency relative to a no-trade alternative.

As the share of permits assigned to the central market increased from $10 \%$ to $100 \%$, actual efficiency gains approximated maximum theoretical gains.

- For shares less than $100 \%$, prices grew higher as the share grew smaller. This means that the price signal given by the mandated market is a poor estimator of the price that a $100 \%$ market would generate. Because the auction price overestimates the efficient price, it thus provides an incentive for additional voluntary trading which could yield further efficiencies.

- Single year permits and multi-year bundles of single year permits resulted in the lowest realized costs relative to the minimum attainable.

Bundling permits did not improve cost efficiency compared to single period issues.

- The large cost savings theoretically available through banking were not realized in the experiments. 


\section{APPROACH}

The experimentalist approach to answering questions is to create artificial markets in a laboratory that mimic the salient features of real markets and to observe what happens. The laboratory is set up in such a way that all communications, financial rewards and penalties, and information are under the strict control of the researchers. Human subjects are paid cash according to how successful they are in achieving their economic goals under the market rules, reward structures, and information circumstances specified by the experiment. By changing the controls. researchers can effectively simulate a wide variety of economic institutions; researchers are not constrained to studying existing economic arrangements.

The Arizona experiments were constructed to focus the subjects on the issue of how many permits to buy. Each subject was given a value schedule, which was not shared with anyone else, that explicitly showed the payment the subject would receive for each of his possible holdings of permits. His profit in each trading period would be the difference between the values of his holdings at the end of the period and the net cost of acquiring permits. His profit over the experiment would be the sum of the profits made at the end of each trading period (twenty-two timed periods). Payment was in cash at the end of the experiment.

In reality, firms would have to engage in a financial analysis of their pollution control costs, operating conditions and options for buying power in order to know the value to them of alternative holdings. The Colorado experiments simply gave each subject the necessary information on control costs and interest costs and left it to the subjects to figure, or learn, their own valuation schedules. By happenstance professional bankers who were expected to be facile in performing the necessary cost analysis were recruited for two experiments. The Colorado experiments simultaneously examined the properties of the permit auction schemes and the ability of the subjects to derive an appropriate valuation schedule for their decision making.

There were substantial differences in what each research group expected of the subjects.

\section{THE ARIZONA EXPERIMENTS ${ }^{2}$}

Dr. Isaac's team first examined the effect of the initial allocation on efficiency and then investigated the efficiency gains attributable to a central, mandated market.

Any costless, initial endowment guarantees the recipient a minimum emissions potential and generates wealth for him. Dr. 'saac ran four experiments in which there was no initial allocation: all permits had to be purchased from the "government." These are called the government auction cases. He also ran four experiments, the revenue neutral cases, in which some of the subjects were given all of the permits. Once the distribution was made, subjects were required to trade in a second price auction. Subjects could retain title to their permits only by submitting a winning bid. If their

\footnotetext{
${ }^{2}$ The Arizona work is described in more detail in Robert Franciosi, R. Mark Isaac, David E. Pingry and Stanley S. Reynolds, "Marketable Acid Rain Emission Permits: An Investigation of Revenue Neutral Auctions," Department of Economics and Economic Science Laboratory, University of Arizona, Tucson, Arizona.
} 
bid was accepted, they would be effectively selling a portion of their initial allocation to themselves. If their bid was rejected, they would lose the permits but they would earn revenues determined by the second price auction. Discriminatory pricing could have been used instead of second price but was not because there was not enough time.

All eight experiments were run under the conditions enumerated in Table 1. The initial endowments and efficient (profit maximizing) first period holdings of each bidder are in Table 2.

Table 1. Common conditions of initial allocation experiments (Arizona)

$\begin{array}{ll}\text { Subjects } & 10 \\ \text { Periods } & 22\end{array}$

Permits by Period

Period 1-7 $\quad 40$

Period 8-11 36

Period 11-15 32

Period 16-20 20

Table 2. First period efficient holdings and initial endowments of subjects

\begin{tabular}{cccccc}
\hline Bidder & $\begin{array}{l}\text { Efficient } \\
\text { Holding }\end{array}$ & Endowment & Bidder & $\begin{array}{c}\text { Efficient } \\
\text { Holding }\end{array}$ & Endowment \\
1 & 4 & 8 & 6 & 2 & 4 \\
2 & 6 & 6 & 7 & 2 & 2 \\
3 & 2 & 6 & 8 & 2 & 2 \\
4 & 4 & 6 & 9 & 6 & 2 \\
5 & 8 & 2 & 10 & 4 & \\
\hline
\end{tabular}

In general, the revenue neutral and government auctions behaved similarly and tracked the competitive ideal (least cost). Figure 1 indicates the average market price obtained from the four revenue neutral and four government auction experiments compared across sequential time periods with the competitive norm. The prices increase in response to the decreasing supply of permits. The efficiencies of the two sets of experiments also follow theoretical efficiency very closely. Efficiency is measured as the percent of theoretical cost savings which the firms capture. Figure 2 displays these results. Both auction mechanisms achieve above $95 \%$ efficiencies, though for each experiment efficiencies occasionally dip as firms experiment with buying strategies to increase profits. 


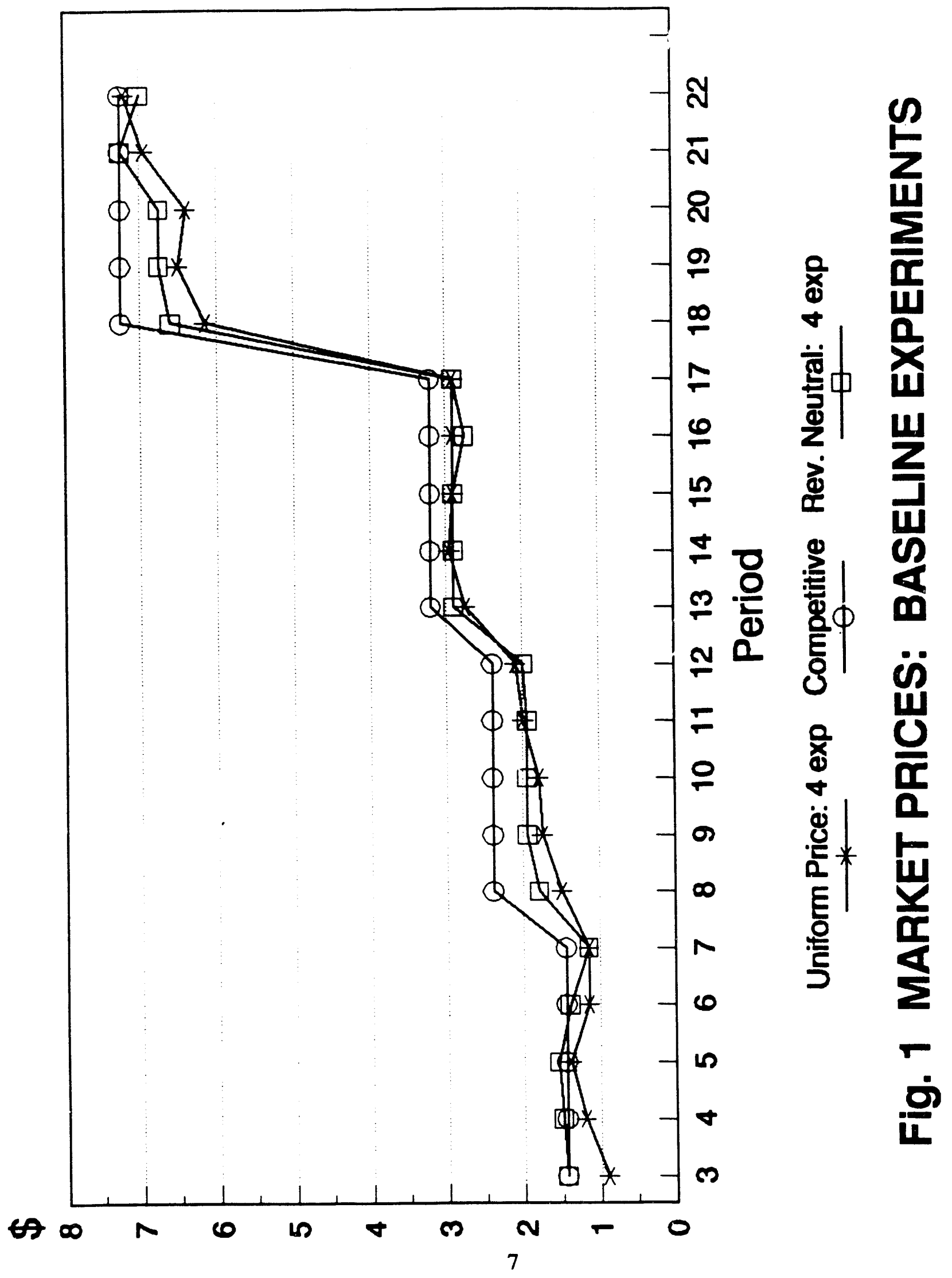




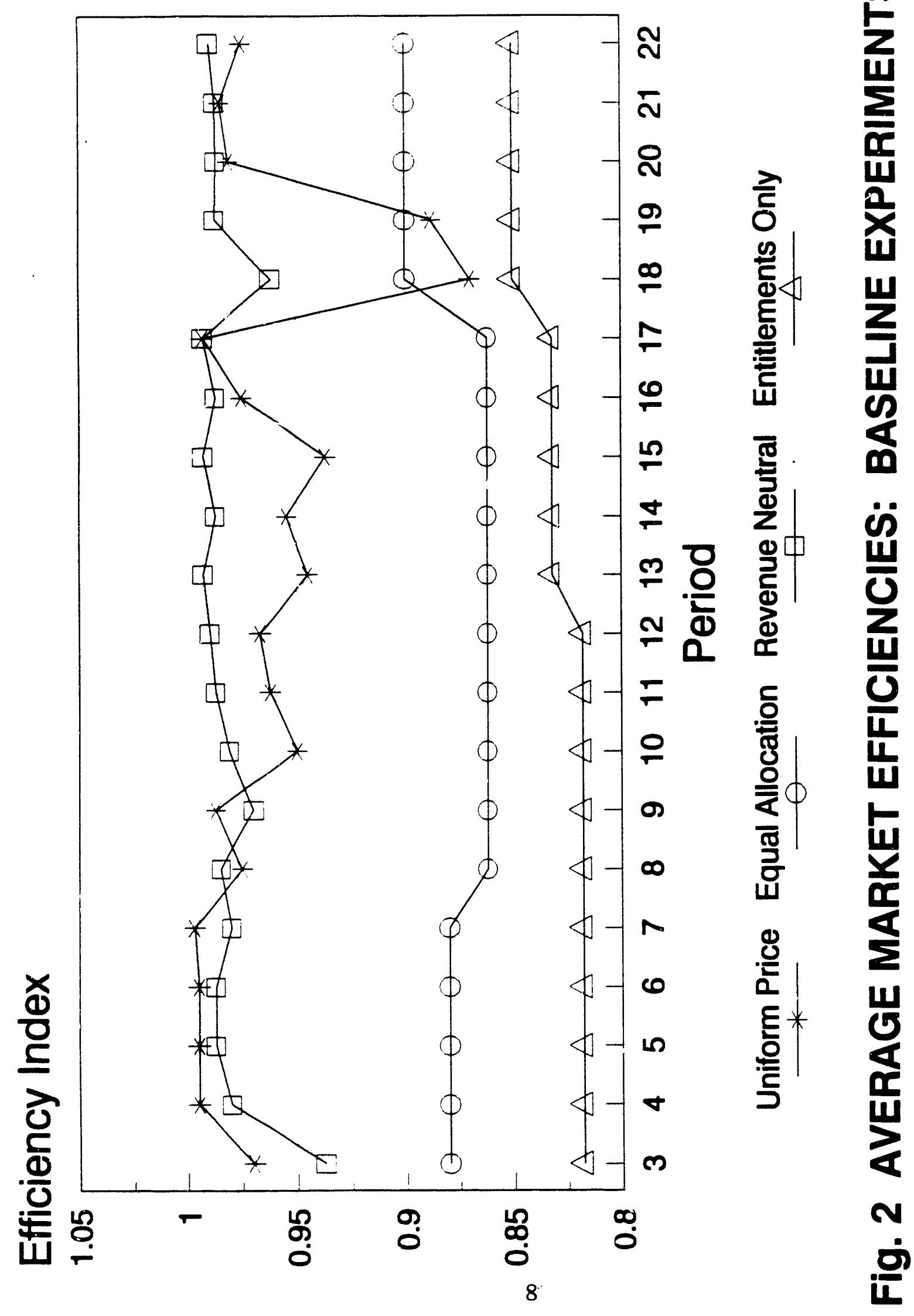


Another measure of performance is the degree to which the auction mechanism encourages firms to "reveal" their true valuations for permits (their marginal pollution abatement costs) through their bids. This can be important because it explains instances where full efficiencies are not achieved. On average, firms underbid their true values in the government auction, but overbid their values substantially in the revenue neutral auction. This is likely due to the fact that, in the revenuc neutral experiments firms with initial allocations could recapture their allocations by bidding artificially high prices, knowing that they would be reimbursed at market price for their contribution to the supply of permits offered for sale. Despite the fact that losses in efficiency due to overbidding werc not evident in these relatively simple experiments, the revenue neutral auction with uniform prices holds open the option for firms initially endowed with permits to hoard these permits, regardless of value, by bidding high, with no loss of revenue. If this behavior were to actually occur in the market for permits it would reduce the desirability of the mechanism.

The second set of four experiments was intended to examine the case where legislation mandated that only a fraction of available permits be entered into the central auction. The experiments were carried out under the worst case assumption that no voluntary trading would occur by fixing the supply of permits at the mandated level. Mandatory market shares of $10 \%, 25 \%$, and $50 \%$ were forced, and the revenues were rebated to the firms supplying the permits.

Theory predicts that prices would increase as the forced market decreases in size. This is because the forced markets commandeered permits proportionally across firms with different abatement costs, so the permits which remain will not be allocated optimally. In other words, a firm in a less than $100 \%$ market with no voluntary traciing will retain permits whose market value exceeds the firm's marginal abatement costs. Since permit price exceeds marginal abatement costs for some utilities, this is a signal to low cost firms about the potential for additional profits from selling permits.

The experiments bear out the theoretical predictions concerning price. As is shown in Fig. 3 , both theoretical and achieved market prices fall as the percent of permits traded rises from $10 \%$ :o $100 \%$. The exact price differences are not important because they result largely from the hypothetical cost conditions used to characterize the firms in the experiment. However, it is clear that for a small forced central market without voluntary trading, market price will far exceed marginal abatement costs. The experiments also demonstrate that firms should be able to capture most of the available efficiencies even when the share of the total available in the auction is small. Figure 4 illustrates the shares of theoretical efficiency firms captured in the experiments, and displays a slight anomaly in the $100 \%$ case where strategic bidding causes a drop in efficiency below that of the $50 \%$ market. Again, the theoretical efficiencies at each share are largely a matter of abatement cost assumptions but the general principle holds. Prices drop and both theoretical and realized efficiencies increase as forced shares increase. Firms tend to exploit efficiencies despite the size of market shares. 


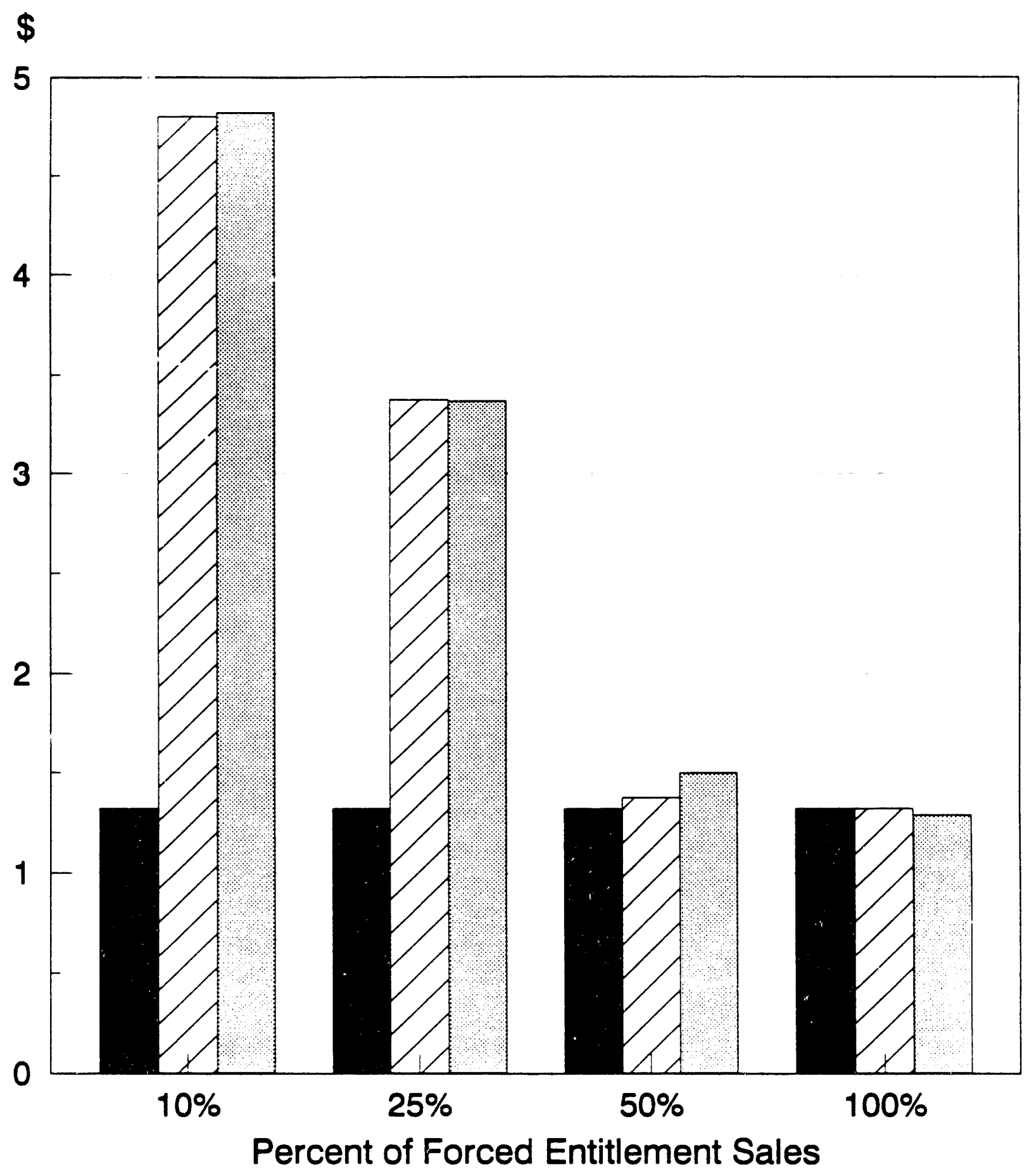

Full Market Comptv. $\square$ Theoretical $\square$ Actual Average

Fig. 3 PARTIAL MARKETS: AVERAGE MARKET PRICES 
Percent
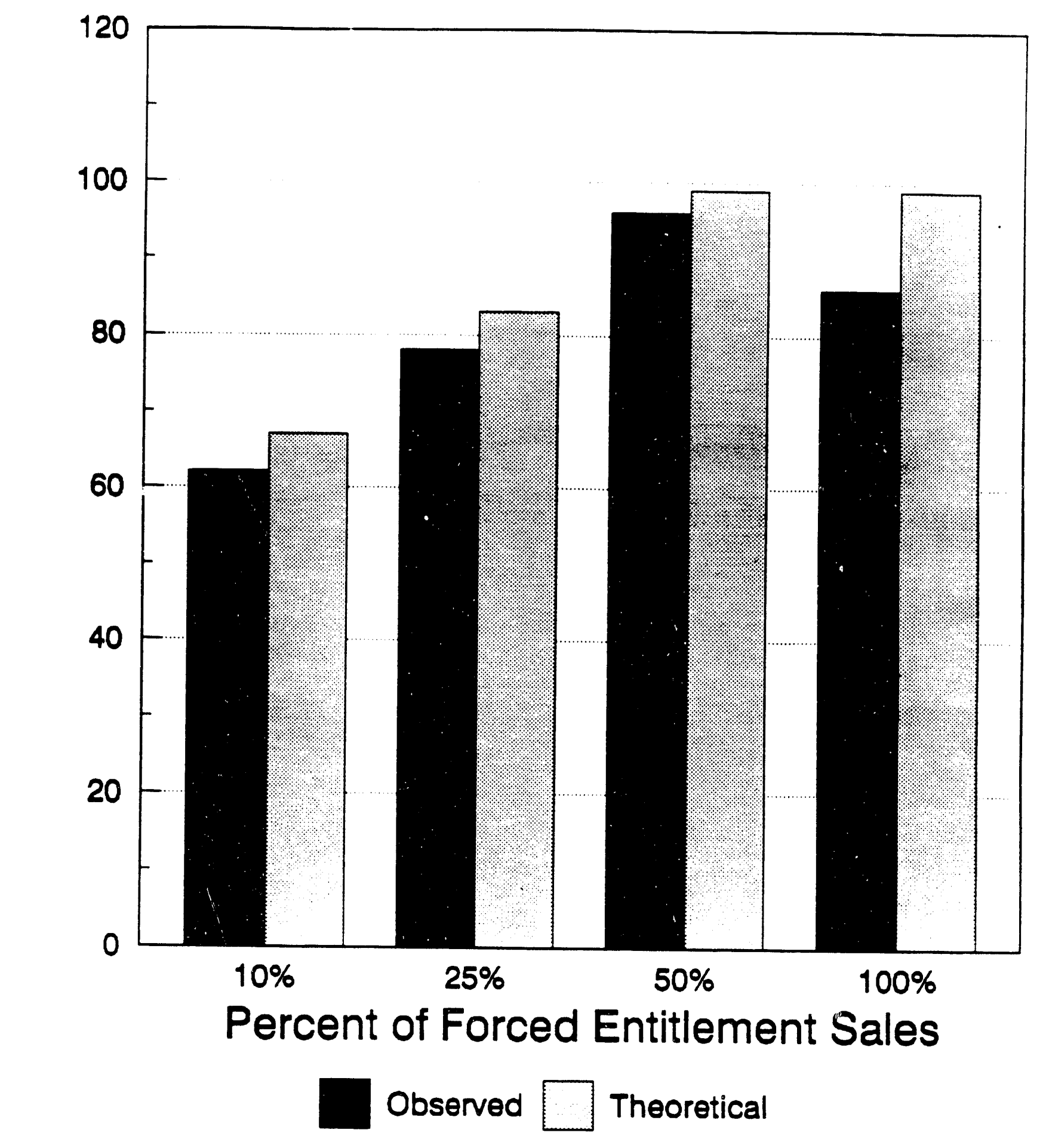

Fig. 4 PARTIAL MARKETS: EFFICIENCY GAINS 


\section{THE COLORADO EXPERIMENTS ${ }^{3}$}

Dr. Jamie Brown-Kruse and Dr. Mark Cronshaw's work concentrated on how the nature of the permits affects efficiency. They examined three alternative definitions of the permit.

The base case defines permits as the right to emit one unit of pollution in a single year. Each firm receives its allocation at the start of each year and is free to use it or sell it in a single price, voluntary auction. There is no mandated central market; the experimental setting can be viewed as the private market that economists expect will arise naturally. Firms can only sell permits that they actually possess and each permit gives the holder the right to emit in the current period. In some treatments the permits also give the right to emit in future periods.

One alternative defines the permit to be a stream of one year permits. Each firm receives its allocation at the start of the experiments and is free to trade the underlying right to all currently unused permits and all future entitlement. In the absence of banking, this is analogous to a market for perpetuities.

The third case defines the permits as a multi-year bundle of five one-year permits. If a firm buys a five-year permit, it will receive one permit in the current year and one in each of the next four years.

Each of these three cases was run with and without banking. Table 3 exhibits the numbers of experiments and subjects for each case.

The Colorado experiments attempted to mimic several features of real markets. The experiments specified that subjects represent high and low emissions cost firms. Experiments with odd number of subjects had one extra high cost firm. Firms were also assumed to be regulated and required to meet demand at a regulated price regardless of their control costs and permit situation. In addition, firms were assumed to face a real interest rate of five percent which was applied to their cash balances and against loans to finance permit purchases and control expenditures. To reflect the emissions reductions required under the proposed legislation, the supply of permits was reduced from 25 per firm after the first five periods to 14 per firm for the next five to seven periods.

The Colorado subjects were required to determine the value of permits to them based upon their own cost functions, initial endowment, and interest rate. The calculations are not trivial, but subjects received no instruction on how to perform the computations and they were not permitted to use calculators. The Arizona experiments by contrast gave each subject a valuation function which defined the value of each permit to that subject.

\footnotetext{
${ }^{3}$ The Colorado work is described in more detail in Jamie Brown-Kruse and Mark B. Crenshaw, "Experimental Study of Marketable Emissions Permits for Reduction of Acid Rain," Department of Economics, University of Colorado, Boulder, Colorado, September 28, 1990.
} 
Table 3. Conditions of permit type experiments

(Colorado)

\begin{tabular}{cll} 
& $\begin{array}{l}\text { No } \\
\text { Banking }\end{array}$ & Banking \\
\cline { 2 - 2 } & & \\
\hline Single Period & 3 & 3 \\
Experiments & $10,10,7$ & $8,9,6$ \\
Subjects & $10,12,12$ & $10,9,12$ \\
Periods & 2 & 2 \\
5 Year Bundles & 9,7 & 3,5 \\
Experiments & 12 & 12 \\
Subjects & 3 & 2 \\
Periods & $4,6,9$ & 5,10 \\
Perpetuity & 12 & 12 \\
Experiments & & \\
Subjects & & \\
Periods & &
\end{tabular}

The market was opened at the start of each period when the firms received their permits. Each firm submitted a private schedule of bids and offers to the computerized market and the implied demand and supply curves were constructed. Prices were set based on the second price mechanism, revenues and permits were redistributed, and all necessary financial transactions were executed. Each firm's financial records were then automatically updated and the next trading period started.

Marketable permits have the theoretical advantage of encouraging least cost behavior by firms. In the Colorado experiments average realized costs were at least $40 \%$ above minimum costs across all cases. The banking results were notably worse; realized costs were over twice as large as minimum cost. Banking seemed to discourage efficient behavior because subjects would hoard permits in an apparent attempt to corner the market. Table 4 is a summary of the realized costs compared to the minimums.

Another way of looking at firm performance is to compare the actual cost savings to the savings available by trading to the least costly position. Table 5 exhibits the results for the single-year permits and for five-year bundles. The perpetuity results are not reported because the subjects did not seem capable of performing the requisite calculations. Base costs in the table are those that a firm would have incurred by simply using its allocation. What comes out of this examination is that banking actually made system costs higher. Firms would have often been better off simply using their initial allocation and not trading at all. 
Table 4. Average ratio of realized cost to minimum cost

No

Type of Permit

Banking

Banking

Single Period

5 Year Bundle

Perpetuity

$\begin{array}{lr}1.4 & 2.4 \\ 1.6 & 2 \\ 2.6 & 2.2\end{array}$

Table 5. Cost Savings (Units of Account anc' \%)

Single Period Permits

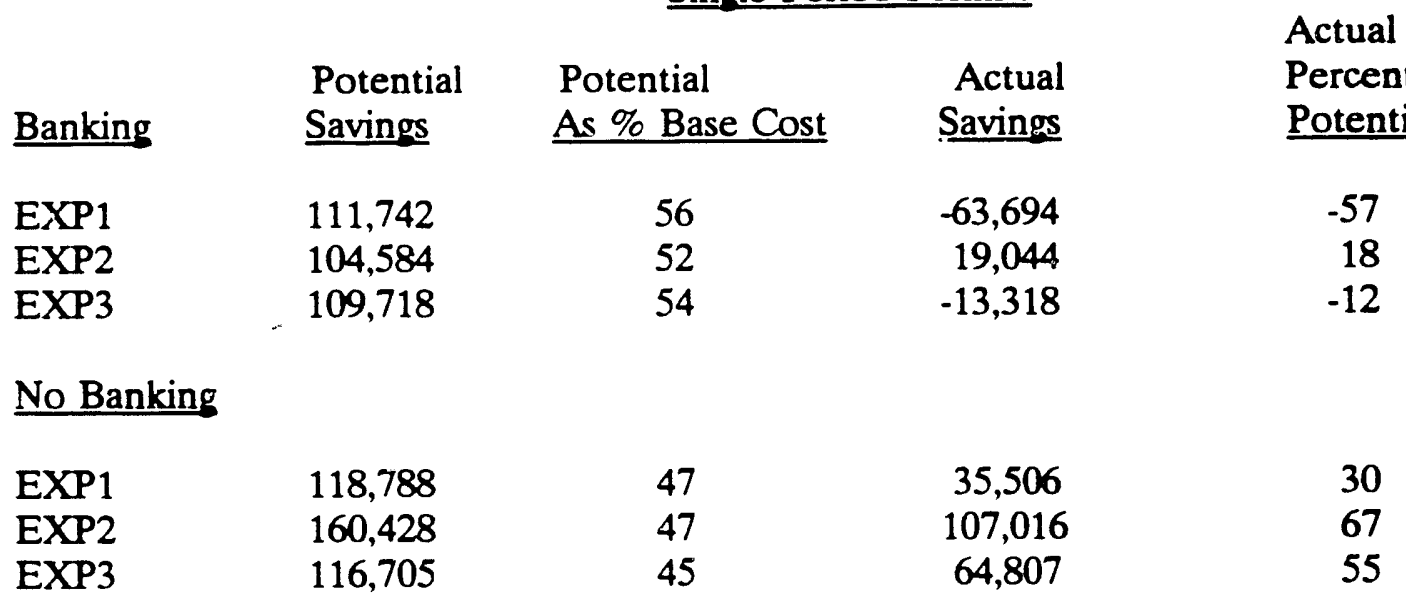

Five-Year Bundles

$\begin{array}{lcccc}\text { Banking } & \begin{array}{l}\text { Potential } \\ \text { Savings }\end{array} & \begin{array}{l}\text { Potential } \\ \text { As \% Base }\end{array} & \begin{array}{l}\text { Actual } \\ \text { Savings }\end{array} & \begin{array}{l}\begin{array}{l}\text { Actual as } \\ \text { Percent of }\end{array} \\ \text { Potential }\end{array} \\ \text { EXP1 } & 64,520 & 52 & -1986 & -3 \\ \text { EXP2 } & 102,588 & 53 & 25,655 & 25\end{array}$

No Banking

\begin{tabular}{lllll} 
EXP1 & 151,966 & 46 & 63,962 & 42 \\
EXP2 & 161,705 & 62 & 18,179 & 16 \\
\hline
\end{tabular}




\section{CONCLUSION}

The experimental results suggest that revenue neutral auctions can be an efficient mechanisin for allocating single period permits. Also, in the absence of private trade, a mandatory market can promote efficiency and encourage private trades. The prices resulting from a small mandatory markci can be so far above marginal control costs as to signal resource misallocation and profitable arbitragc opportunities.

The experiments also raised the issue that the potential cost savings from banking may not be realized. One explanation is that the computational burden was too great for the subjects. Given the opportunities for large gains from banking, most economists would assume that real utilities will quickly master the financial calculations. The other side of the argument is that banking facilitates inefficient hoarding by relieving managers from financial pressure to put permite to good use beforc they expire. Unfortunately, the experiments did not give an unambiguous answer.

\section{POSTSCRIPT}

Since this paper was written, Congress passed a Clean Air Act. The auction in the new law is defined to include a free distribution of rights to utilities, a central market characterized by price discrimination, a pro-rate rebate of the resulting revenues to original holders of the permits, banking, bundling of some permits, a price ceiling of $\$ 1,500$ (in 1990 dollars) per ton of sulfur dioxide, and various special accounts. 


\section{INTERNAL DISTRIBUTION}

$\begin{array}{ll}1-9 . & \text { K. R. Ballew } \\ 10 . & \text { D. R. Baumgardner } \\ 11-60 . & \text { D. J. Bjornstad } \\ 61 . & \text { T. J. Blasing } \\ 62 . & \text { J. M. Bownds } \\ 63 . & \text { B. L. Bush } \\ 64 . & \text { J. B. Cannon } \\ 65 . & \text { T. R. Curlee } \\ 66 . & \text { P. S. Gillis } \\ 67 . & \text { L. J. Hill } \\ 68 . & \text { E.L. Hillsman } \\ 69 & \text { M. A. Kuliasha } \\ 70 . & \text { R. Lee }\end{array}$

71. P. N. Leiby

72. V. C. Mei

73. R. D. Perlack

74. D. E. Reichle

$75 . \quad$ C. G. Rizy

76. R. B. Shelton

$77 . \quad$ D. P. Vogt

78. ORNL Patent Office

79. Central Research Library

$70 . \quad$ Document Reference Section

71-73. Laboratory Records

74. Laboratory Records-RC

\section{EXTERNAL DISTRIBUTION}

75. B. G. Buchanan, Computer Science Department, University of Pittsburgh, 206 Mineral Industries Building, Pittsburgh, PA 15260

76. J. j. Cuttica, Vice President, End Use, Research and Development, Gas Research Institute, 8600 W. Bryn Mawr Avenue, Chicago, II 60631

77-81. Douglas R. Hale, Energy Information Administration, U.S. Department of Energy, 1000 Independence Avenue S.W., Washington, D.C. 20585

82. A. Hirsch, Vice President, Environmental Sciences and Director, Washington Operations. Midwest Research Institute, 5109 Leesburg Pike, Suite 414, Falls Church, VA 22041

83. D. E. Morrison. 333 Oxford Road, East Lansing, MI 48823

84. M. Williams, Professor, Department of Economics, Northern Illinois University, DeKalb. IL 60115

85. Office of Assistant Manager for Energy Research and Development, DOE-ORO, P.O. Box 2001, Oak Ridge, TN 38831-8600

86-95. OSTI, U.S. Department of Energy, P.O. Box 62, Oak Ridge, TN 37831 

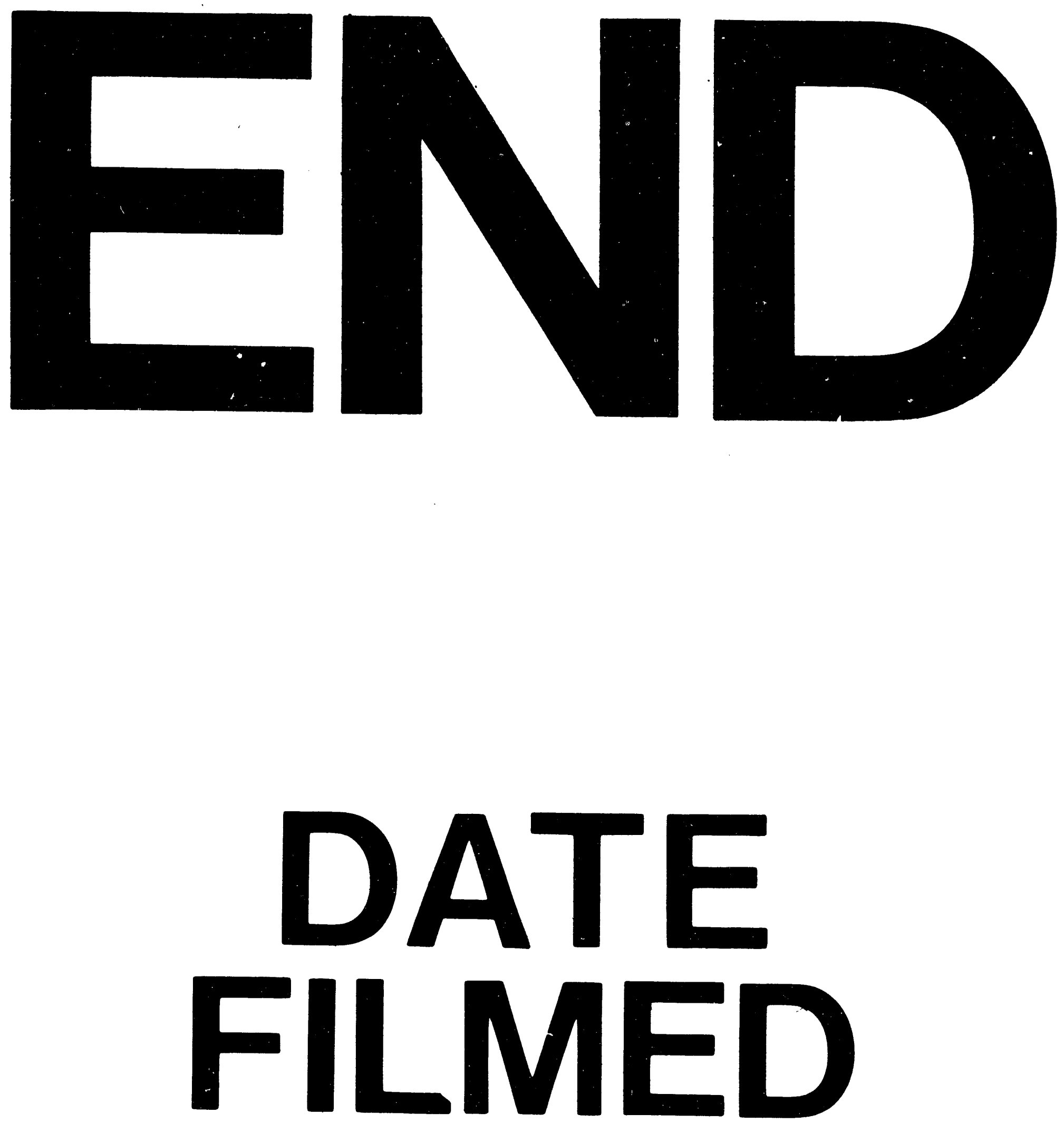

I

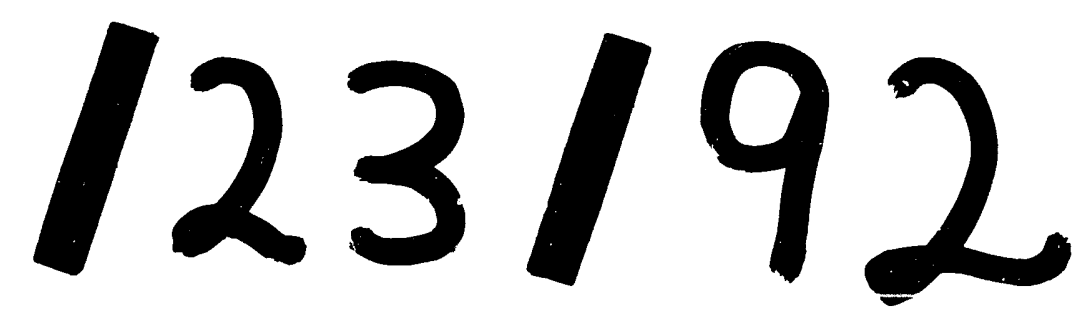




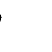

I 